\title{
Up in the air: Untethered Factors of Auxin Response [version
}

\section{1; peer review: 5 approved]}

\author{
Samantha K. Powers, Lucia C. Strader
}

Department of Biology, Washington University in St. Louis, St. Louis, MO, 63130-4899, USA

V1 First published: 03 Feb 2016, 5(F1000 Faculty Rev):133
https://doi.org/10.12688/f1000research.7492.1

Latest published: 03 Feb 2016, 5(F1000 Faculty Rev):133

https://doi.org/10.12688/f1000research.7492.1

\section{Abstract}

As a prominent regulator of plant growth and development, the hormone auxin plays an essential role in controlling cell division and expansion. Auxin-responsive gene transcription is mediated through the TRANSPORT INHIBITOR RESPONSE1/AUXIN SIGNALING F-BOX (TIR1/AFB) pathway. Roles for TIR1/AFB pathway components in auxin response are understood best, but additional factors implicated in auxin responses require more study. The function of these factors, including S-Phase Kinase-Associated Protein 2A (SKP2A), SMALL AUXIN UP RNAs (SAURS), INDOLE 3-BUTYRIC ACID RESPONSE5 (IBR5), and AUXIN BINDING PROTEIN1 (ABP1), has remained largely obscure. Recent advances have begun to clarify roles for these factors in auxin response while also raising additional questions to be answered.

\section{Keywords}

auxin, cell division, gene

\section{Open Peer Review}

Approval Status

$\begin{array}{lllll}1 & 2 & 3 & 4 & 5\end{array}$

version 1

03 Feb 2016

Faculty Reviews are review articles written by the prestigious Members of Faculty Opinions. The articles are commissioned and peer reviewed before publication to ensure that the final, published version is comprehensive and accessible. The reviewers who approved the final version are listed with their names and affiliations.

1. Nihal Dharmasiri, Texas State University-San Marcos, San Marcos, USA

2. Dolf Weijers, Wageningen University and Research Centre, Wageningen, The Netherlands

3. Richard M. Napier, University of Warwick, Coventry, UK

4. Mark Estelle, University of California, San Diego, La Jolla, USA

5. Juan Carlos del Pozo, INIA-CBGP - Scientific and Technological Park of the UPM Campus Montegancedo, Madrid, Spain

Any comments on the article can be found at the 
end of the article.

Corresponding author: Lucia C. Strader (strader@wustl.edu)

Competing interests: The authors declare that they have no competing interests.

Grant information: This research was supported by the William H. Danforth Plant Science Fellowship Program (to S.K.P.), the National Science Foundation (IOS-1453750 to L.C.S.) the National Institutes of Health (R01 GM112898-01 to L.C.S.).

Copyright: ๑ 2016 Powers SK and Strader LC. This is an open access article distributed under the terms of the Creative Commons Attribution License, which permits unrestricted use, distribution, and reproduction in any medium, provided the original work is properly cited.

How to cite this article: Powers SK and Strader LC. Up in the air: Untethered Factors of Auxin Response [version 1; peer review: 5 approved] F1000Research 2016, 5(F1000 Faculty Rev):133 https://doi.org/10.12688/f1000research.7492.1

First published: 03 Feb 2016, 5(F1000 Faculty Rev):133 https://doi.org/10.12688/f1000research.7492.1 


\section{Introduction}

The plant hormone auxin plays a vital role in nearly every aspect of plant growth and development ${ }^{1}$. Auxin-responsive gene expression relies on the TRANSPORT INHIBITOR RESPONSE1/AUXIN SIGNALING F-BOX (TIR1/AFB) pathway to trigger the expression of genes controlling auxin-regulated cell division, expansion, and differentiation ${ }^{2,3}$. Whereas the role of the TIR1/AFB pathway in the auxin signal transduction pathway has been well established, the existence of additional components raises the possibility that we have yet to uncover the entire story of auxin signaling.

Auxin signaling through the TIR1/AFB pathway involves three major protein families (Figure 1A) - the auxin-binding TIR1/AFB F-box proteins, the AUXIN RESPONSE FACTOR (ARF) transcription factors, and the AUXIN/INDOLE-3-ACETIC ACID INDUCIBLE (Aux/IAA) repressor proteins ${ }^{2,3}$. In the absence of auxin, the Aux/IAA proteins repress activity of the ARF transcription factors ${ }^{4}$. In the presence of auxin, the TIR1/AFB F-box proteins, which participate in a SCF (Skp1-Cullin-F-box) E3 ubiquitin ligase, interact with Aux/IAA repressor proteins to form a co-receptor, with auxin acting as the "molecular glue" ${ }^{4-6}$. This interaction results in ubiquitylation and consequent degradation of the Aux/IAA repressor proteins through the $26 \mathrm{~S}$ proteasome, relieving repression of the ARF transcription factors and allowing for auxin-regulated gene transcription ${ }^{7}$. Interactions among these three protein families is now understood at a molecular level ${ }^{2}$ and provides a signal transduction pathway that controls auxin-responsive gene transcription in plants. For recent reviews of the TIR1/AFB pathway, please see 1,3.

In addition to components of the TIR1/AFB pathway, other factors implicated in auxin response have been identified - however, roles for these components in regulating auxin signaling are much less understood. Although insight into the function of some of these factors, such as S-PHASE KINASE-ASSOCIATED PROTEIN 2A (SKP2A), SMALL AUXIN UP RNAs (SAURs), INDOLE 3-BUTYRIC ACID RESPONSE5 (IBR5), and AUXIN BINDING PROTEIN1 (ABP1), has been elusive, roles for these factors in regulating auxin outputs are slowly starting to be determined. In this commentary, we explore recent advances in our understanding of these factors and their roles in auxin response.

\section{SKP2A}

Whereas extensive work has gone into understanding the auxinbinding capabilities of TIR 1 and its downstream effects on auxinregulated developmental responses (Figure 1A), less is known about the molecular mechanisms that directly connect auxin to its role in cell division. Several cell cycle genes are upregulated by auxin $^{8}$ and other cell cycle genes contain auxin response elements in their promoter regions; however, these do not appear to be upregulated by auxin ${ }^{8}$, suggesting that additional mechanisms linking auxin to cell division control may exist. Heterologously expressed SKP2A, an F-box protein involved in regulating the proteolysis of cell-cycle-related transcription factors ${ }^{9,10}$, directly binds auxin ${ }^{11}$ and may provide a mechanism for auxin-mediated regulation of cell division (Figure 1B).

The retinoblastoma-E2F pathway regulates the cell cycle through the interaction of E2F proteins with dimerization proteins (DPs) to form transcription factors that either activate or repress the expression of genes involved in cell cycle progression ${ }^{12}$. SKP2A incorporates into an SCF complex ${ }^{9,13}$ with E3 ubiquitin ligase activity $^{13}$. Intriguingly, binding of auxin by SKP2A is necessary for degradation of E2FC and its dimerization partner DPB through the $26 \mathrm{~S}$ proteasome ${ }^{11}$. Degradation of E2FC and DPB relieves repression of cell cycle control genes to allow cell cycle progression ${ }^{9,10}$. In addition to regulating the degradation of $\mathrm{E} 2 \mathrm{FC} / \mathrm{DPB}$, auxin binding promotes proteolysis of SKP2A itself ${ }^{13}$, perhaps setting up a system in which auxin prevents SKP2A overfunction ${ }^{11}$. The $s k p 2 a$ mutant hyperaccumulates E2FC and DPB protein ${ }^{10,13}$. Further, expressing a SKP2A variant unable to bind auxin in the mutant background fails to rescue this phenotype, suggesting that auxin binding by SKP2A is required for E2FC/DPB degradation ${ }^{11}$. Overexpression of $S K P 2 A$ results in increased cell division and induces lateral root primordia (LRP) formation, a process known to be dependent on auxin signaling 9 . The molecular phenotypes of the skp2a mutant combined with the phenotypes of the SKP $2 A$ overexpression lines suggest a role for SKP2A in promoting auxin-regulated cell division.

Involvement of SKP2A in auxin binding and consequent degradation of the cell-cycle regulators E2FC and DPB implicate this F-box as a missing link connecting auxin regulation to cell division; however, relatively little is known about this pathway. Many questions remain for SKP2A roles in auxin-regulated cell division control. For example, SKP2A directly binds auxin and functions as part of an SCF complex responsible for targeting downstream components for degradation - are additional factors, other than E2FC and DPB, targeted for degradation by SKP2A to contribute to auxin response? Further, are activating E2F+/EP+ complexes similarly regulated by the proteasome? What is the effect on plant growth and development if this auxin-induced degradation of these factors is disrupted? There appear to be no gross effects on plant morphology in the skp2a mutant; is this because of redundancy or is it indicative of a minor role for SKP2A in plant growth and development? Answering these questions will inform our understanding of SKP2A roles in mediating auxin effects on cell division.

\section{SAUR proteins}

Auxin regulation downstream of the TIR1/AFB pathway involves the induction of the early auxin response gene family SAURs. Initially discovered as auxin-induced transcripts in elongating soybean hypocotyls using a hybridization screen ${ }^{14}$, multiple lines of evidence have been used to assign SAUR functions in auxin-related aspects of plant growth and development, including cell expansion, tropic growth, and apical hook development ${ }^{15}$. Although SAURs represent the largest family of early auxin response genes, SAUR function in mediating auxin effects has only recently begun to be elucidated.

$\mathrm{Ca}^{2+}$ is a well-known secondary messenger regulating developmental and physiological aspects of plant growth ${ }^{16}$. Auxin has been proposed as a $\mathrm{Ca}^{2+}$ activating signal ${ }^{17}$; however, mechanisms connecting $\mathrm{Ca}^{2+}$ to auxin signaling have remained largely elusive. SAUR proteins from multiple species interact with calmodulin $(\mathrm{CaM})$ in a calcium-dependent manner ${ }^{18-20}$ and additional SAUR proteins are predicted to contain a CaM-binding site ${ }^{15}$. Binding of SAUR70 to $\mathrm{CaM}$ or CaM-like proteins has been confirmed in planta ${ }^{19}$; however, further studies will be necessary to determine the extent and functional relevance of SAUR-CaM interactions in auxin-regulated calcium signaling. 


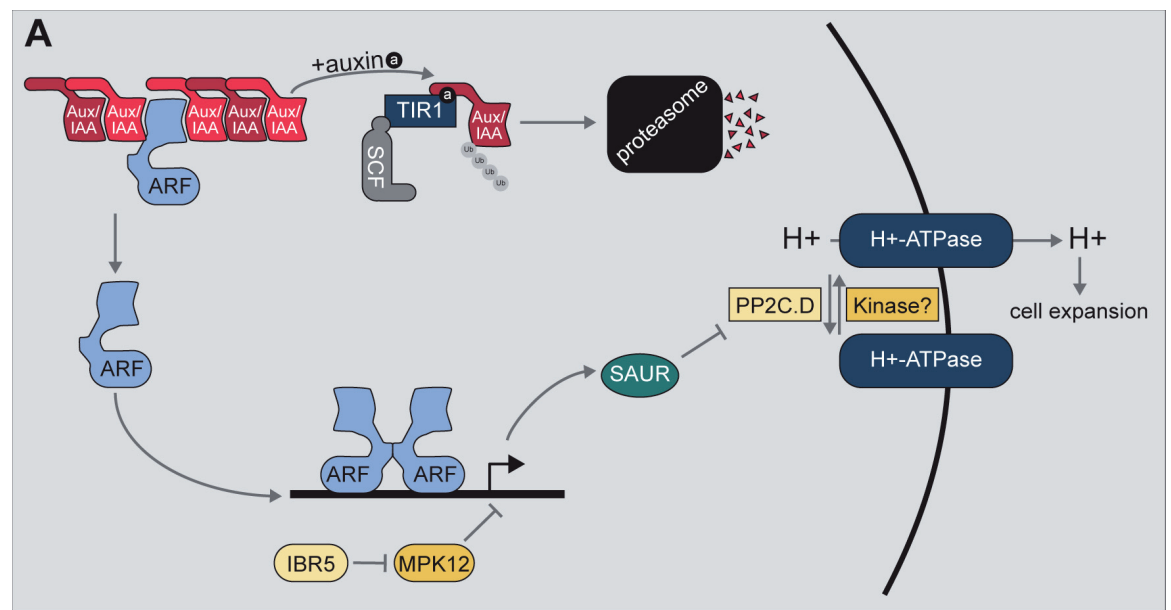

B
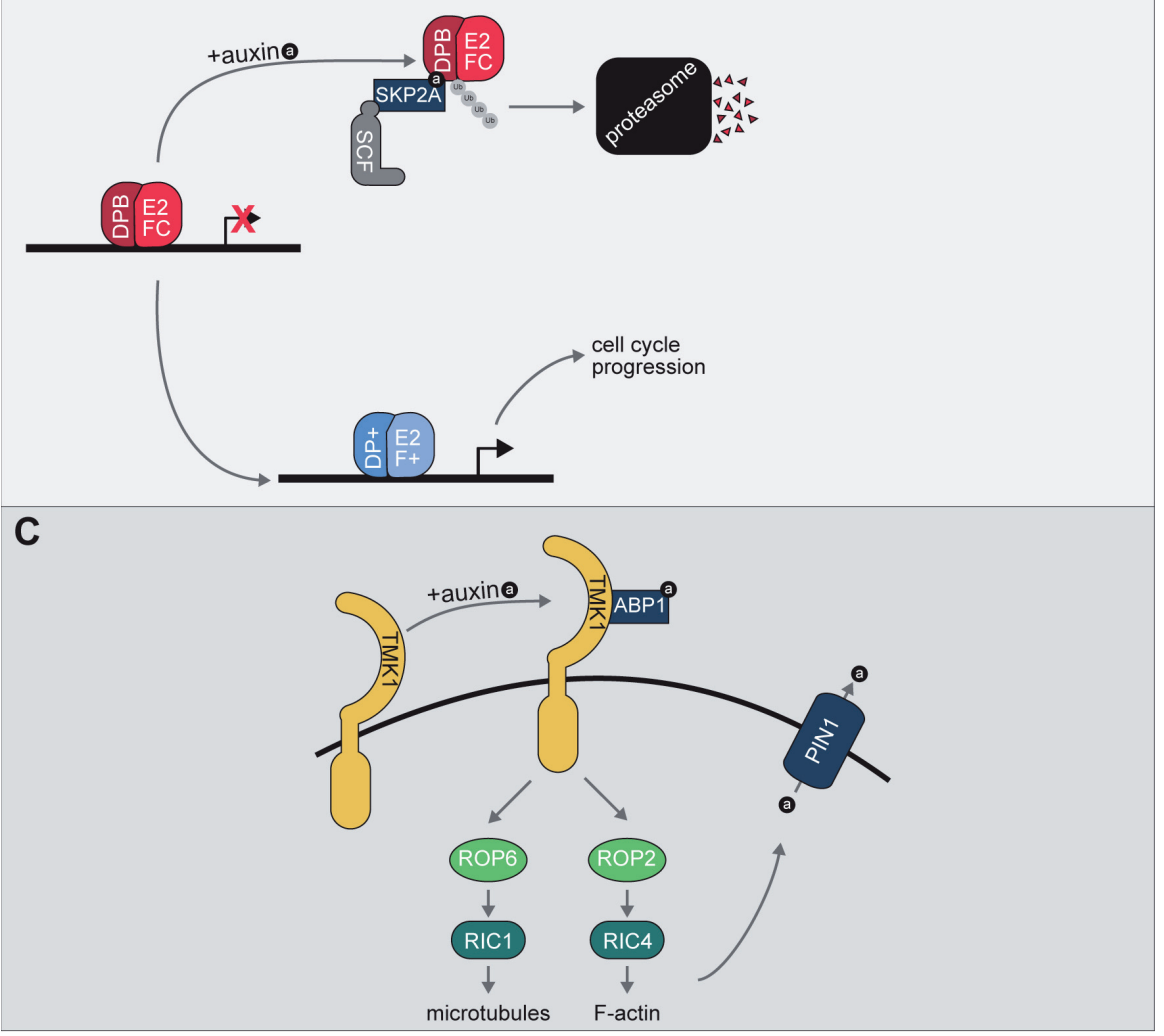

Figure 1. Auxin signal transduction pathways. (A) Model of the TRANSPORT INHIBITOR RESPONSE1/AUXIN SIGNALING F-BOX (TIR1/AFB) signaling pathway. Auxin promotes the formation of the TIR1/AFB Auxin/INDOLE-3-ACETIC ACID INDUCIBLE (Aux/IAA) co-receptor to promote the ubiquitylation and subsequent degradation of the Aux/IAA repressor. Aux/IAA degradation relieves repression of AUXIN RESPONSE FACTOR (ARF) transcription factors, allowing for auxin-responsive gene expression. One of the transcript families upregulated by auxin is the SAUR family. The small SMALL AUXIN UP RNA (SAUR) proteins encoded by these transcripts have been suggested to play roles in multiple processes, one of which is interaction with and inhibition of members of the PP2C.D family of phosphatases, which act to regulate $\mathrm{H}^{+}$-ATPase activity. Further, INDOLE-3-BUTYRIC ACID RESPONSE5 (IBR5) and MITOGEN-ACTIVATED PROTEIN KINASE12 (MPK12) have been implicated in regulating auxin-responsive gene transcription; this regulation is not through destabilization of the Aux/IAA repressors, suggesting a yet-to-be discovered mechanism of regulating auxin-responsive gene expression. For in-depth reviews of the TIR/AFB signaling pathway, please refer to 1,3. For an in-depth review of SAUR proteins, please refer to 15. (B) Model of the S-PHASE KINASE ASSOCIATED PROTEIN 2A (SKP2A) signaling pathway. E2FC/DPB repress expression of cell cycle genes. The F-box protein SKP2A binds auxin and promotes degradation of E2FC/DPB in an auxin-dependent manner. Degradation of E2FC/DPB relieves repression of cell cycle genes and allows for binding by activating E2F+/DP+ complexes. For an in-depth review of the SKP2A signaling pathway, please refer to 8. (C) Model of the putative AUXIN BINDING PROTEIN1 (ABP1) signaling pathway. Apoplastic auxin is bound by ABP1, which allows for interaction with the TRANSMEMBRANE KINASE RECEPTOR (TMK) family of leucine-rich repeat receptor-like kinases. ABP1 binding of auxin regulates RHO-LIKE GTPASE 2 (ROP2) and ROP6 activation and binding to ROP interactive CRIB motif-containing proteins (RICs) proteins to positively regulate microtubule polymerization and F-actin polymerization and also alter PINFORMED1 protein localization to alter auxin efflux. For an in-depth review of the ROP/RIC system, please refer to 54. 
Several SAUR subfamilies, including SAUR19-24, are likely involved in cell expansion ${ }^{21}$; however, mechanistic insight into SAUR roles in this auxin-regulated response has been lacking. Auxin has long been proposed to induce cell elongation through an acid growth mechanism ${ }^{22}$, in which auxin is responsible for activating $\mathrm{H}^{+}$-ATPases to acidify the extracellular matrix, in turn activating expansins and promoting solute and water uptake to drive cell expansion. Recently, Spartz et al. ${ }^{23}$ determined that SAUR proteins promote phosphorylation of the C-terminal autoinhibitory domain of $\mathrm{PM} \mathrm{H}^{+}$-ATPases, causing activation. In addition, several SAUR proteins interact with a group of the D-clade PP2C phosphatases to inhibit phosphatase activity ${ }^{23,24}$. These phosphatases likely modulate the phosphorylation status of $\mathrm{H}^{+}$-ATPases ${ }^{23}$. Thus, SAURs likely act to inhibit the PP2C.D inhibitors of $\mathrm{H}^{+}$-ATPase activity, suggesting a role for the SAUR proteins as positive effectors in auxin-mediated cell expansion through regulation of the PM $\mathrm{H}^{+}$-ATPase activity. If PP2C.D deactivates $\mathrm{H}^{+}$-ATPase activity through de-phosphorylation, it then follows that a kinase is necessary to activate $\mathrm{H}^{+}$-ATPases. Many protein kinases have been proposed to regulate $\mathrm{H}^{+}$-ATPase activity ${ }^{25}$ - perhaps one of these functions in an auxin-dependent manner to regulate $\mathrm{H}^{+}$-ATPases. Further, the identified SAUR-CaM interactions combined with the recently identified roles for SAUR proteins in regulating phosphatases raise the possibility that SAUR proteins could act as a link between calcium signaling, auxin, and phosphatase activity.

Recent studies have provided increasing evidence of SAURs' importance in auxin-regulated plant growth and development. The large families of these proteins identified in widespread plant species suggest multiple and diverse SAUR functions in auxin response. One possible mechanism for SAUR regulation of such varied auxin-related plant responses may be provided by combinatorial diversity in SAUR-PP2C.D interactions. In Arabidopsis, there are 81 SAURs $^{26}$ and nine PP2C.D family members ${ }^{24}$, many of which have been proposed to have differential expression patterns throughout the plant ${ }^{27}$. Varying SAUR-PP2C.D combinations may regulate the phosphorylation status of distinct downstream elements to regulate different aspects of auxin response ${ }^{15}$. Interaction experiments using the different SAUR-PP2C.D combinations may uncover whether SAUR proteins from additional clades also interact with these phosphatases. Further, the distinct subcellular localization and various developmental processes associated with individual SAUR proteins ${ }^{15}$ suggest that SAUR targets in addition to $\mathrm{H}^{+}$-ATPases likely exist. Whereas recent studies have finally begun to illuminate SAUR molecular functions in auxin response, further research will surely uncover additional mechanisms connecting the SAUR proteins to auxin signaling.

\section{IBR5 and MPK12}

Auxin pathway roles for IBR5 and its interacting MAP kinase MPK12 remain enigmatic. The $i b r 5$ mutant was initially isolated for its resistance to the auxin precursor indole-3-butyric acid $(\text { IBA })^{28}$, but subsequent studies revealed that $i b r 5$ was resistant to all tested auxins ${ }^{29}$ and auxin transport inhibitors ${ }^{30}$. In addition to reduced physiological responses to exogenous auxin application, ibr5 mutants display developmental phenotypes ${ }^{29,31,32}$ and reduced auxin-responsive transcription ${ }^{29-32}$, suggesting roles for IBR5 in the auxin signaling pathway.
IBR5 encodes a dual-specificity protein phosphatase ${ }^{29}$; related phosphatases de-phosphorylate MAP kinases ${ }^{33,34}$. Dual-specificity protein phosphatases are distinct from the PP2C-type phosphatases associated with SAUR activity (see above). IBR5 splice variants appear to play distinct roles in regulating plant growth and auxin responses and at least some of these roles may be independent of its catalytic activity ${ }^{31}$. However, the IBR5 catalytic cysteine is necessary for auxin responsive inhibition of root elongation ${ }^{30,31}$ and IBR5 can de-phosphorylate the Arabidopsis MPK12 in vitro ${ }^{35}$. Further, RNAi lines of MPK12 display auxin resistance ${ }^{35}$, suggesting that IBR5 and MPK12 play opposing roles in regulating auxin responsiveness.

$i b r 5$ double mutants with other mutants that dampen auxin responses, including tirl, axrl, and auxl, exhibit additive auxin resistance in one or more bioassays ${ }^{30}$. Most notably, combining $i b r 5$ with an auxin receptor mutant, tirl, greatly enhances auxin resistance relative to either parent ${ }^{30}$, consistent with the possibility that IBR5 effects on auxin response are TIR1 independent. Similar to other auxin-resistant mutants, ibr5 exhibits decreased levels of auxin-responsive transcripts $^{29-32}$. However, unlike other characterized auxin-response mutants, Aux/IAA proteins are not stabilized in $i b r 5$ and are actually destabilized ${ }^{30,31}$, again suggesting that IBR5 modulates auxin signaling in a manner unique from other known auxin response regulators. ARF proteins mediate auxin-responsive gene transcription and the primary known mechanism of ARF regulation is repression by Aux/IAA proteins ${ }^{3}$. The decreased auxin-responsive gene transcription ${ }^{29-32}$ combined with destabilized Aux/IAA repressor proteins ${ }^{30,31}$ observed in ibr5 mutants suggest that either Aux/ IAA destabilization is not the sole mechanism of regulating ARF activity or that there exists an additional auxin signaling pathway that ends in regulating the same gene targets as the TIR1/AFB pathway. Elucidating IBR5 and MPK12 targets may help differentiate between these possibilities. Recently, IBR5 was found to interact with SUPPRESSOR OF G2 ALLELE SKP1 (SGT1b), HEAT SHOCK PROTEIN90 (HSP90), and the Toll/interleukin-1 receptor domains of CHILLING SENSITIVE 3 (CHS3), SUPPRESSOR OF NPR1-1 (SNC1), and RESISTANT TO P. SYRINGAE 4 (RPS4) ${ }^{36}$. IBR5 interaction with SGT1b may provide a mechanism for IBR5 regulation of auxin responses; mutants defective in SGT1b/ETA3 have been isolated as enhancers of tirl auxin resistance, perhaps by modulating $26 \mathrm{~S}$ proteasome activity ${ }^{37}$. SGT1b is a co-chaperone with HSP90. Further, TIR1 has recently been identified as a HSP90 client and HSP90 plays roles in integrating temperature and auxin signaling $^{38}$; perhaps IBR5 is an additional HSP90 client to allow temperature and auxin response integration.

\section{ABP1 and TMK1}

Opinions about ABP1, first discovered over 40 years ago, have varied over the years. ABP1 has been proposed to act as an apoplastic auxin receptor whose downstream signal transduction pathway regulates cytoskeletal rearrangement and internalization of auxin transporters in response to auxin ${ }^{39-41}$. Study of roles for ABP1 in plant auxin signaling was limited by the reported embryo lethality of null abpl alleles ${ }^{42-45}$. In the absence of a viable allele, the field made progress in understanding ABP1 function by use of ABP1 knockdown lines, provided by expression of an inducible ABP1 antisense transcript or of an inducible single-chain fragment variable from 
a monoclonal antibody raised to $\mathrm{ABP} 1^{46}$. The identification of an EMS-generated TILLING line, abpl-5, carrying a point mutation in the auxin-binding pocket of ABP $1^{47,48}$ allowed for intense study of ABP1 functions in auxin signaling and spurred an explosion of ABP1-related discoveries, uncovering roles for this elusive auxinbinding protein in a wide variety of processes throughout plant development ${ }^{39}$. These new findings allowed for widespread acceptance of $\mathrm{ABP} 1$ as a bona fide auxin receptor ${ }^{41}$.

The recognition of ABP1 as an auxin receptor, however, has once again been called into question. A recent report showing that new abpl null alleles display no obvious auxin-related or developmental phenotypes ${ }^{49}$ was contradictory to earlier reports of the embryo lethality of the abp1-1 null allele ${ }^{42-45}$ and the physiological and molecular phenotypes displayed by conditional knockdown and abpl-5 alleles ${ }^{39}$. This conflict was recently partially reconciled by the discovery that the embryo lethal phenotypes of $a b p 1-1$ and abpl-1s were caused by a loss of the neighboring BELAYA SMERT gene rather than from loss of $A B P 1^{50,51}$ and that the abp1-1 allele, which is null for $A B P 1$, displays no obvious morphological phenotypes when the $B S M$ defect is rescued in the mutant ${ }^{50}$. Further, at least some of the phenotypes observed in the abp1-5 TILLING allele may be the result of a background mutation in PHYTOCHROME $B^{52}$. Future work with new $A B P 1$ genetic resources ${ }^{49,51}$ will be necessary to clarify the role of ABP1 in auxin signaling and plant development and will determine whether $a b p 1$ null alleles display molecular phenotypes.

The auxin-binding affinity of ABP1 combined with its widespread conservation throughout plants would suggest an important role for ABP1; however, lack of physiological phenotypes in the null mutants ${ }^{49,50}$ would suggest that ABP1 does not play a prominent role in Arabidopsis development. At this time, auxin-related roles for downstream components in the ABP1 pathway (Figure 1C) including the TRANSMEMBRANE KINASE (TMK) family of receptor-like kinases ${ }^{53}$ and the ROP-RIC system ${ }^{54}$ remain unchallenged. This is a turbulent time in the ABP1 field as new discoveries are being made and roles (or lack thereof) for this signaling pathway in plant growth and development are being clarified. Roles for ABP1 in auxin response and development have once again become controversial; clearly more work will be needed to reconcile conflicting reports in this area.

\section{Conclusions and future directions}

The existence of factors in addition to the components of the well-established TIR1/AFB pathway suggests that we have yet to uncover the entire story of auxin response. Recent advances in the field are slowly bringing to light roles in auxin signaling for each of these factors - SKP2A, the SAUR proteins, IBR5, and ABP1 however, many questions still remain. In addition, although the TIR/AFB pathway appears to be well characterized, new structural data suggest that there are additional regulatory aspects of this pathway, including ARF proteins acting as molecular DNA calipers and ARF and Aux/IAA protein multimerization ${ }^{2,55}$ that have yet to be fully explored. Further research will undoubtedly uncover new regulatory mechanisms for the TIR/AFB pathway and molecular roles for these untethered factors in auxin signaling - the sky is the limit!

\section{Abbreviations}

ABP1, AUXIN BINDING PROTEIN1; AFB, AUXIN SIGNALING F-BOX; ARF, AUXIN RESPONSE FACTOR; Aux/IAA, Auxin/ INDOLE-3-ACETIC ACID INDUCIBLE; bHLH, basic HelixLoop-Helix; CaM, Calmodulin; DP, Dimerization Protein; IBR5, INDOLE-3-BUTYRIC ACID RESPONSE5; MPK12, MITOGENACTIVATED PROTEIN KINASE12; ROP, RHO-LIKE GTPASE; SAUR, SMALL AUXIN UP RNA; SCF, Skp1-Cullin-F-box; SKP2A, S-PHASE KINASE ASSOCIATED PROTEIN 2A; TIR1, TRANSPORT INHIBITOR RESPONSE1; TMK, TRANSMEMBRANE KINASE RECEPTOR.

\section{Competing interests}

The authors declare that they have no competing interests.

\section{Grant information}

This research was supported by the William H. Danforth Plant Science Fellowship Program (to S.K.P.), the National Science Foundation (IOS-1453750 to L.C.S.) the National Institutes of Health (R01 GM112898-01 to L.C.S.).

\section{Acknowledgements}

We are grateful to Tara Enders, Elizabeth Frick, and Marta Michniewicz-Paciorek for critical comments on the manuscript.
1. Enders TA, Strader LC: Auxin activity: Past, present, and future. Am J Bot. 2015 102(2): 180-196.

PubMed Abstract | Publisher Full Text

2. Korasick DA, Jez JM, Strader LC: Refining the nuclear auxin response pathway through structural biology. Curr Opin Plant Biol. 2015; 27: 22-28. PubMed Abstract | Publisher Full Text | Free Full Text

3. Wang R, Estelle M: Diversity and specificity: auxin perception and signaling through the TIR1/AFB pathway. Curr Opin Plant Biol. 2014; 21: 51-58. PubMed Abstract | Publisher Full Text | Free Full Text

4. Chapman EJ, Estelle M: Mechanism of auxin-regulated gene expression in plants. Annu Rev Genet. 2009; 43: 265-285. PubMed Abstract | Publisher Full Text
5. F Dharmasiri N, Dharmasiri S, Estelle M: The F-box protein TIR1 is an auxin
receptor. Nature. 2005; 435(7041): 441-445.
PubMed Abstract | Publisher Full Text | F1000 Recommendation
6. F Kepinski S, Leyser O: The Arabidopsis F-box protein TIR1 is an auxin
receptor. Nature. 2005; 435(7041): 446-451.
PubMed Abstract | Publisher Full Text | F1000 Recommendation
7. Salehin M, Bagchi R, Estelle M: SCFIR/AFB-based auxin perception:
mechanism and role in plant growth and development. Plant Cell. 2015;
27(1): 9-19.
PubMed Abstract | Publisher Full Text | Free Full Text
8. F Del Pozo JC, Manzano C: Auxin and the ubiquitin pathway. Two players-one 
target: the cell cycle in action. J Exp Bot. 2014; 65(10): 2617-2632. PubMed Abstract | Publisher Full Text | F1000 Recommendation

9. F del Pozo JC, Boniotti MB, Gutierrez C: Arabidopsis E2Fc functions in cell division and is degraded by the ubiquitin-SCFAtSKP2 pathway in response to light. Plant Cell. 2002; 14(12): 3057-3071.

PubMed Abstract | Publisher Full Text | Free Full Text | F1000 Recommendation

10. del Pozo JC, Diaz-Trivino S, Cisneros N, et al:: The balance between cell division and endoreplication depends on E2FC-DPB, transcription factors regulated by the ubiquitin-SCF ${ }^{\text {SKP2A }}$ pathway in Arabidopsis. Plant Cell. 2006; 18(9): 2224-2235. PubMed Abstract | Publisher Full Text | Free Full Text

11. F Jurado S, Abraham Z, Manzano C, et al:: The Arabidopsis cell cycle F-box protein SKP2A binds to auxin. Plant Cell. 2010; 22(12): 3891-3904. PubMed Abstract | Publisher Full Text | Free Full Text | F1000 Recommendation

12. Gutierrez C, Ramirez-Parra E, Castellano MM, et al.: $G_{1}$ to $\mathbf{S}$ transition: more than a cell cycle engine switch. Curr Opin Plant Biol. 2002; 5(6): 480-486. PubMed Abstract | Publisher Full Text

13. F Jurado S, Triviño SD, Abraham Z, et al.: SKP2A protein, an F-box that regulates cell division, is degraded via the ubiquitin pathway. Plant Signal Behav 2008; 3(10): 810-812.

PubMed Abstract | Publisher Full Text | Free Full Text | F1000 Recommendation

14. McClure BA, Guilfoyle T: Characterization of a class of small auxin-inducible soybean polyadenylated RNAs. Plant Mol Biol. 1987; 9(6): 611-623. PubMed Abstract | Publisher Full Text

15. F Ren H, Gray WH: SAUR Proteins as Effectors of Hormonal and Environmental Signals in Plant Growth. Mol Plant. 2015; 8(8): 1153-1164. PubMed Abstract | Publisher Full Text | F1000 Recommendation

16. Hepler PK: Calcium: a central regulator of plant growth and development Plant Cell. 2005; 17(8): 2142-2155.

PubMed Abstract | Publisher Full Text | Free Full Text

17. Vanneste S, Friml J: Calcium: The Missing Link in Auxin Action. Plants. 2013 2(4): 650-675.

Publisher Full Text

18. F Knauss S, Rohrmeier T, Lehle L: The auxin-induced maize gene ZmSAUR2 encodes a short-lived nuclear protein expressed in elongating tissues. J Biol Chem. 2003; 278(26): 23936-23943. PubMed Abstract | Publisher Full Text | F1000 Recommendation

19. F Popescu SC, Popescu GV, Bachan S, et al: Differential binding of calmodulinrelated proteins to their targets revealed through high-density Arabidopsis protein microarrays. Proc Natl Acad Sci U S A. 2007; 104(11): 4730-4735. PubMed Abstract | Publisher Full Text | Free Full Text | F1000 Recommendation

20. Yang T, Poovaiah BW: Molecular and biochemical evidence for the involvement of calcium/calmodulin in auxin action. J Biol Chem. 2000; 275(5): 3137-3143. PubMed Abstract | Publisher Full Text

21. F Spartz AK, Lee SH, Wenger JP, et al.: The SAUR19 subfamily of SMALL AUXIN UP RNA genes promote cell expansion. Plant J. 2012; 70(6): 978-990. PubMed Abstract | Publisher Full Text | Free Full Text | F1000 Recommendation

22. Rayle DL, Cleland RE: The Acid Growth Theory of auxin-induced cell elongation is alive and well. Plant Physiol. 1992; 99(4): 1271-1274. PubMed Abstract |Publisher Full Text| Free Full Text

23. F Spartz AK, Ren H, Park MY, et al:: SAUR Inhibition of PP2C-D Phosphatases Activates Plasma Membrane $\mathrm{H}^{+}$-ATPases to Promote Cell Expansion in Arabidopsis. Plant Cell. 2014; 26(5): 2129-2142.

PubMed Abstract | Publisher Full Text | Free Full Text | F1000 Recommendation

24. Schweighofer A, Hirt H, Meskiene I: Plant PP2C phosphatases: emerging functions in stress signaling. Trends Plant Sci. 2004; 9(5): 236-243. PubMed Abstract | Publisher Full Tex

25. Haruta M, Gray WM, Sussman MR: Regulation of the plasma membrane proton pump ( $\mathbf{H}^{+}$-ATPase) by phosphorylation. Curr Opin Plant Biol. 2015; 28: 68-75. PubMed Abstract | Publisher Full Text | Free Full Text

26. Hagen G, Guilfoyle T: Auxin-responsive gene expression: genes, promoters and regulatory factors. Plant Mol Biol. 2002; 49(3-4): 373-385. PubMed Abstract | Publisher Full Text

27. F Tovar-Mendez A, Miernyk JA, Hoyos E, et al:: A functional genomic analysis of Arabidopsis thaliana PP2C clade D. Protoplasma. 2014; 251(1): 265-271. PubMed Abstract | Publisher Full Text | F1000 Recommendation

28. Zolman BK, Bartel B: An Arabidopsis indole-3-butyric acid-response mutant defective in PEROXIN6, an apparent ATPase implicated in peroxisomal function. Proc Natl Acad Sci U S A. 2004; 101(6): 1786-1791. PubMed Abstract | Publisher Full Text | Free Full Text

29. Monroe-Augustus M, Zolman BK, Bartel B: IBR5, a dual-specificity phosphatase-like protein modulating auxin and abscisic acid responsiveness in Arabidopsis. Plant Cell. 2003; 15(12): 2979-2991. PubMed Abstract | Publisher Full Text | Free Full Text

30. F Strader LC, Monroe-Augustus M, Bartel B: The IBR5 phosphatase promotes Arabidopsis auxin responses through a novel mechanism distinct from TIR1-mediated repressor degradation. BMC Plant Biol. 2008; 8: 41. PubMed Abstract | Publisher Full Text | Free Full Text | F1000 Recommendation

31. F Jayaweera T, Siriwardana C, Dharmasiri S, et al:: Alternative splicing of Arabidopsis IBR5 pre-mRNA generates two IBR5 isoforms with distinct and overlapping functions. PLOS One 2014; 9(8): e102301.

PubMed Abstract | Publisher Full Text | Free Full Text | F1000 Recommendation
32. F Johnson KL, Ramm S, Kappel C, et al:: The Tinkerbell (Tink) Mutation dentifies the Dual-Specificity MAPK Phosphatase INDOLE-3-BUTYRIC ACID-RESPONSE5 (IBR5) as a Novel Regulator of Organ Size in Arabidopsis. PLOS One. 2015; 10(7): e0131103.

PubMed Abstract | Publisher Full Text | Free Full Text | F1000 Recommendation

33. Camps M, Nichols A, Arkinstall S: Dual specificity phosphatases: a gene family for control of MAP kinase function. FASEB J. 2000; 14(1): 6-16. PubMed Abstract

34. Keyse SM: An emerging family of dual specificity MAP kinase phosphatases. Biochem Biophys Acta. 1995; 1265(2-3): 152-160. PubMed Abstract | Publisher Full Text

35. F Lee JS, Huh KW, Bhargava A, et al: Comprehensive analysis of protein-protein interactions between Arabidopsis MAPKs and MAPK kinases helps define potential MAPK signalling modules. Plant Signal Behav. 2008; 3(12): 1037-1041. PubMed Abstract | Publisher Full Text | Free Full Text | F1000 Recommendation

36. F Liu J, Yang H, Bao F, et al:: IBR5 Modulates Temperature-Dependent, R Protein CHS3-Mediated Defense Responses in Arabidopsis. PLOS Genet. 2015; 11(10): e1005584.

PubMed Abstract | Publisher Full Text | Free Full Text | F1000 Recommendation

37. Gray WM, Muskett PR, Chuang HW, et al.: Arabidopsis SGT1b is required for SCF TR1-mediated auxin response. Plant Cell. 2003; 15(6): 1310-1319. PubMed Abstract | Publisher Full Text | Free Full Text

38. Wang $\mathrm{R}$, Zhang $\mathrm{Y}$, Kieffer $\mathrm{M}$, et al.: HSP90 regulates temperature-dependent seedling growth in Arabidopsis by stabilizing the auxin co-receptor F-box protein TIR1. Nat Commun. 2016; 7: 10269.

PubMed Abstract | Publisher Full Text

39. Feng M, Kim JY: Revisiting Apoplastic Auxin Signaling Mediated by AUXIN BINDING PROTEIN 1. Mol Cells. 2015; 38(10): 829-835. PubMed Abstract | Publisher Full Text | Free Full Text

40. Sauer M, Robert S, Kleine-Vehn J: Auxin: simply complicated. J Exp Bot. 2013; 64(9): 2565-2577.

PubMed Abstract | Publisher Full Tex

41. Shi JH, Yang ZB: Is ABP1 an auxin receptor yet? Mol Plant. 2011; 4(4): 635-640. PubMed Abstract | Publisher Full Text | Free Full Text

42. Chen JG, Ullah $\mathrm{H}$, Young JC, et al.: ABP1 is required for organized cell elongation and division in Arabidopsis embryogenesis. Genes Dev. 2001; 15(7): 902-911. PubMed Abstract | Publisher Full Text | Free Full Text

43. Meinke D, Muralla R, Sweeney $\mathrm{C}$, et al:: Identifying essential genes in Arabidopsis thaliana. Trends Plant Sci. 2008; 13(9): 483-491. PubMed Abstract | Publisher Full Text

44. Sassi M, Ali O, Boudon F, et al:: An auxin-mediated shift toward growth isotropy promotes organ formation at the shoot meristem in Arabidopsis. Curr Biol. 2014; 24(19): 2335-2342.

PubMed Abstract | Publisher Full Text

45. Tzafrir I, Pena-Muralla R, Dickerman A, et al:: Identification of genes required for embryo development in Arabidopsis. Plant Physiol. 2004; 135(3): 1206-1220. PubMed Abstract | Publisher Full Text | Free Full Text

46. Leblanc N, David K, Grosclaude J, et al: A novel immunological approach establishes that the auxin-binding protein, $\mathrm{Nt}$-abp1, is an element involved in auxin signaling at the plasma membrane. J Biol Chem. 1999; 274(40): 28314-28320

PubMed Abstract | Publisher Full Tex

47. Robert S, Kleine-Vehn J, Barbez E, et al:: ABP1 mediates auxin inhibition of clathrin-dependent endocytosis in Arabidopsis. Cell. 2010; 143(1): 111-121. PubMed Abstract | Publisher Full Text | Free Full Text

48. Xu T, Wen M, Nagawa S, et al.: Cell surface- and rho GTPase-based auxin signaling controls cellular interdigitation in Arabidopsis. Cell. 2010; 143(1): 99-110.

PubMed Abstract | Publisher Full Text | Free Full Text

49. $\mathrm{F}$ Gao $\mathrm{Y}$, Zhang $\mathrm{Y}$, Zhang $\mathrm{D}$, et al:: Auxin binding protein 1 (ABP1) is not required for either auxin signaling or Arabidopsis development. Proc Natl Acad SciU S A. 2015; 112(7): 2275-2280.

PubMed Abstract | Publisher Full Text | Free Full Text | F1000 Recommendation

50. Dai X, Zhang Y, Zhang D, et al.: Embryonic lethality of Arabidopsis abp1-1 is caused by deletion of the adjacent BSM gene. Nat Plants. 2015; 15183. Publisher Full Text

51. F Michalko J, Dravecká M, Bollenbach T, et al.: Embryo-lethal phenotypes in early abp1 mutants are due to disruption of the neighboring BSM gene [version 1; referees: 3 approved]. F1000Res. 2015; 4: 1104 PubMed Abstract | Publisher Full Text | Free Full Text | F1000 Recommendation

52. F Enders TA, Oh S, Yang Z, et al.: Genome Sequencing of Arabidopsis abp1-5 Reveals Second-Site Mutations That May Affect Phenotypes. Plant Cell. 2015; 27(7): 1820-1826

PubMed Abstract | Publisher Full Text | Free Full Text | F1000 Recommendation

53. F Xu T, Dai N, Chen J, et al:: Cell surface ABP1-TMK auxin-sensing complex activates ROP GTPase signaling. Science. 2014; 343(6174): 1025-1028. PubMed Abstract | Publisher Full Text | Free Full Text | F1000 Recommendation

54. Miyawaki KN, Yang Z: Extracellular signals and receptor-like kinases regulating ROP GTPases in plants. Front Plant Sci. 2014; 5: 449. PubMed Abstract | Publisher Full Text | Free Full Tex

55. Dinesh DC, Villalobos LI, Abel S: Structural Biology of Nuclear Auxin Action. Trends Plant Sci. 2015; pii: S1360-1385(15)00278-2.

PubMed Abstract | Publisher Full Text 


\section{Open Peer Review}

\section{Current Peer Review Status:}

\section{Editorial Note on the Review Process}

Faculty Reviews are review articles written by the prestigious Members of Faculty Opinions. The articles are commissioned and peer reviewed before publication to ensure that the final, published version is comprehensive and accessible. The reviewers who approved the final version are listed with their names and affiliations.

\section{The reviewers who approved this article are:}

\section{Version 1}

\section{Juan Carlos del Pozo}

INIA-CBGP - Scientific and Technological Park of the UPM Campus Montegancedo, Madrid, Spain Competing Interests: No competing interests were disclosed.

\section{Mark Estelle} UC San Diego Division of Biological Sciences, University of California, San Diego, La Jolla, CA, USA Competing Interests: No competing interests were disclosed.

\section{Richard M. Napier} School of Life Sciences, University of Warwick, Coventry, UK Competing Interests: No competing interests were disclosed.

4. Dolf Weijers Wageningen University and Research Centre, Wageningen, The Netherlands Competing Interests: No competing interests were disclosed.

\section{Nihal Dharmasiri} Department of Biology, Texas State University-San Marcos, San Marcos, TX, USA Competing Interests: No competing interests were disclosed. 
The benefits of publishing with F1000Research:

- Your article is published within days, with no editorial bias

- You can publish traditional articles, null/negative results, case reports, data notes and more

- The peer review process is transparent and collaborative

- Your article is indexed in PubMed after passing peer review

- Dedicated customer support at every stage

For pre-submission enquiries, contact research@f1000.com 